\title{
Examining self-efficacy levels of football referees
}

\author{
Authors' Contribution: \\ A Study Design \\ B Data Collection \\ C Statistical Analysis \\ D Data Interpretation \\ E Manuscript Preparation \\ F Literature Search \\ G Funds Collection \\ Sercan Kural ${ }^{1}$ ABCDEF, Faruk Aydin² ABCDEF \\ ${ }^{1}$ Faculty of Sport Sciences, Bartın University, Bartın, Turkey \\ 2 Faculty of Sport Sciences, Lokman Hekim University, Ankara, Turkey
}

abstract

Background: This study examined football referees' self-efficacy according to various variables.

Material and methods: The sample included 278 football referees (Mean ${ }_{\text {age }}=26.00 \pm 5.72$ years) from different classes in the Ankara province. Participants, selected by convenience sampling, completed the Referee Self-Efficacy Scale (REFS). After testing the main assumptions of parametric tests, t-tests and one-way analysis of variance (ANOVA) were used for data analysis.

Results: The t-tests revealed no significant difference in gender and education. As for the ANOVA results, there were significant differences in REFS dimensions "physical competency," "game knowledge," and "decisionmaking" in age; "game knowledge" and "decision-making" in income; and "physical competency" and "decision-making" in the refereeing level.

Conclusions: Self-efficacy levels of football referees vary according to refereeing categories, income levels, and age.

Key words: football, referees, self-efficacy.

\section{article details}

Article statistics: Word count: 2,463; Tables: 6; Figures: 0; References: 24

Received: May 2021; Accepted: December 2021; Published: December 2021

Full-text PDF: http://www.balticsportscience.com

Copyright @ Gdansk University of Physical Education and Sport, Poland

Indexation: Celdes, Clarivate Analytics Emerging Sources Citation Index (ESCl), CNKI Scholar (China National Knowledge Infrastructure), CNPIEC, DOAJ, EBSCO - Central \& Eastern European Academic Source, EBSCO - SPORTDiscus, EBSCO Discovery Service, Google Scholar, Index Copernicus, J-Gate, Naviga (Softweco, Primo Central (ExLibris), ProQuest - Family Health, ProQuest - Health \& Medical Complete, ProQuest - Illustrata: Health Sciences, ProQuest Nursing \& Allied Health Source, Summon (Serials Solutions/ProQuest, TDOne (TDNet), Ulrich's Periodicals Directory/ ulrichsweb, WorldCat (OCLC)

Funding: This research received no specific grant from any funding agency in the public, commercial, or not-for-profit sectors. Authors have declared that no competing interest exists.

This is an open access article distributed under the terms of the Creative Commons Attribution-Non-Commercial-NoDerivatives 4.0 International (https://creativecommons.org/licenses/by-nc-nd/4.0/), which permits use, distribution, and reproduction in any medium, provided the original work is properly cited, the use is non-commercial and is otherwise in compliance with the license. 


\section{INTRODUCTION}

Football is a leisure activity that supports an entertaining, dynamic, purposeful, and active lifestyle [1]. With $4 \%$ of the world population showing active interest in it, football is one of today's most popular sports [2-5]. The high popularity of this sport also affects its referees.

Referees and their assistants are responsible for ensuring that the competitive efforts of players conform to the rules of the game and that the results are fairly received [6,7]. Even in a universal sport like football, the referee's duty is to maintain fairness and enhance integrity before and after the game [8,9]. Preserving integrity and ensuring justice during and after games is extremely challenging for referees. They have a tough job during the game because of multiple aspects that should be considered, the need for quick and complex decisionmaking, the implications of their actions, the number of people involved in the match, and often the violent nature of spectators at sporting events. They perform numerous tasks, including evaluating players' actions during the match, making quick decisions, managing the match, paying attention to multiple aspects of the game, maintaining order, and resolving disputes [10,11]. All these factors not only make referees' job complex but also increase the scope for mistakes. Referees are often criticized for their decisions because of possible mistakes and subjectivity in assessing actions [10, 12]. Mistakes made while officiating can cause a loss of confidence, high anxiety, and increased stress levels in referees [10, 13-15].

Self-efficacy is a psychological mechanism that reduces performance-related stress and anxiety levels. Self-efficacy refers to an individual's belief that they can successfully execute necessary behaviors that can produce the desired outcomes in a certain domain and that they can carry out different levels of performance successfully [16, 17]. Referee's self-efficacy is defined as the degree to which referees believe that they have the capacity to perform successfully in matches they officiate [17].

This study is based on Bandura's theory of self-efficacy [16], and it examines the self-efficacy levels of football referees. Therefore, it is aimed to examine the self-efficacy of football referees according to various variables.

\section{MATERIAL AND METHOD}

\section{RESEARCH MODEL}

This study used a relational survey model, which is a quantitative research method that reveals the current condition of the research subject [18].

\section{PARTICIPANTS}

The study sample consisted of 278 football referees from the Ankara province in four categories - candidate, city, class, and top-class referees - during the 2020-2021 season.

\section{DATA COLLECTION TOOLS}

The data collection tool used in this study had two sections. The first section included personal information of the participants. The second section included the Referee SelfEfficacy Scale (REFS), which was developed by Myers et al. [19] and adapted into Turkish by Karaçam and Pulur [20]. The items per dimension of the scale are as follows: physical competency, five; pressure, three; decision-making, three; communication, four; and game knowledge, three. The REFS is rated on a five-point Likert scale (from Strongly Disagree $=1$ to Strongly Agree = 5). 


\section{DATA ANALYSIS}

Skewness and kurtosis values were analyzed first to test the normality of distribution. T-tests and one-way analysis of variance (ANOVA) were conducted to determine the difference between variables. The internal consistency coefficient Cronbach's alpha was calculated to assess the reliability of the data. The internal consistency coefficient was 89 for the overall REFS and 0.84 for physical competency, .74 for pressure, .80 for decision-making, .92 for communication, and .83 for game knowledge.

\section{RESEARCH QUESTIONS}

1. Is there a difference between the opinions of football referees regarding their selfefficacy levels according to their age?

2. Is there a difference between the opinions of football referees regarding their selfefficacy levels according to their gender?

3. Is there a difference between the opinions of football referees regarding their selfefficacy levels according to their education level?

4. Is there a difference between the opinions of football referees on self-efficacy levels according to the income level?

5. Is there a difference between the opinions of football referees on self-efficacy levels according to their refereeing level?

\section{RESULTS}

The personal information of study participants is provided in Table 1. Of the total sample, $37 \%$ of the participants were aged $18-23$ years, $37.8 \% 24-29$ years, $19.1 \% 30-35$ years, $4.1 \% 36-41$ years, and $1.4 \% \geq 42$ years. Of the participants, $88.8 \%$ were male and $11.2 \%$ were female. Regarding educational levels, $83.8 \%$ and $16.2 \%$ of the participants were university and high school graduates, respectively. The data on income show that $40.3 \%$ of the sample had an income level of $\leq 407 \$$. Among the referee categories, class referees accounted for $42.8 \%$ of the referees.

Table 1. Personal information of the study participants

\begin{tabular}{|c|c|c|c|}
\hline \multicolumn{2}{|c|}{ Participants' characteristics } & $f$ & $\%$ \\
\hline \multirow{6}{*}{ Age } & $18-23$ & 105 & 37.8 \\
\hline & $24-29$ & 105 & 37.8 \\
\hline & $30-35$ & 53 & 19.1 \\
\hline & $36-41$ & 11 & 4.0 \\
\hline & $\geq 42$ & 4 & 1.4 \\
\hline & Total & 278 & 100 \\
\hline \multirow{3}{*}{ Gender } & Female & 31 & 11.2 \\
\hline & Male & 247 & 88.8 \\
\hline & Total & 278 & 100 \\
\hline \multirow{3}{*}{ Education } & High school graduate & 45 & 16.2 \\
\hline & University graduate & 233 & 83.8 \\
\hline & Total & 278 & 100 \\
\hline \multirow{6}{*}{ Income level } & $\leq 407 \$$ & 112 & 40.3 \\
\hline & $408-432 \$$ & 30 & 10.8 \\
\hline & $433-576 \$$ & 35 & 12.6 \\
\hline & $577-721 \$$ & 21 & 7.6 \\
\hline & $\geq 722 \$$ & 80 & 28.8 \\
\hline & Total & 278 & 100 \\
\hline
\end{tabular}




\begin{tabular}{cccc} 
Participants' characteristics & $\mathrm{f}$ & $\%$ \\
\hline & Candidate referee & 55 & 19.8 \\
Refereeing level & City referee & 92 & 33.1 \\
& Class referee & 119 & 42.8 \\
& Top-class referee & 12 & 4.3 \\
& Total & 278 & 100 \\
\hline
\end{tabular}

The independent t-test analysis revealed no statistically significant gender difference in football referees' mean scores on the physical competency ( $t=-1.40 ; p>0.05)$, game knowledge $(t=-1.21 ; p>0.05)$,decision-making $(t=-.886 ; p>0.05)$, pressure $(t=-1.62$; $\mathrm{p}>0.05)$, and communication $(\mathrm{t}=-.289 ; \mathrm{p}>0.05)$ dimensions of the RFES (Table 2 ).

Table 2. Results of the t-test analysis for gender

\begin{tabular}{|c|c|c|c|c|c|c|c|}
\hline Dimensions & Gender & $n$ & $\bar{x}$ & Sd. & Df & $\mathrm{t}$ & p* \\
\hline \multirow{2}{*}{ Physical competency } & Female & 31 & 4.39 & .66 & \multirow{10}{*}{276} & \multirow{2}{*}{-1.40} & \multirow{2}{*}{.162} \\
\hline & Male & 247 & 4.53 & .50 & & & \\
\hline \multirow{2}{*}{ Game knowledge } & Female & 31 & 4.61 & .50 & & \multirow{2}{*}{-1.21} & \multirow{2}{*}{.225} \\
\hline & Male & 247 & 4.70 & .39 & & & \\
\hline \multirow{2}{*}{ Decision-making } & Female & 31 & 4.61 & .45 & & 006 & 376 \\
\hline & Male & 247 & 4.69 & .46 & & -.886 & $.3 / 6$ \\
\hline \multirow{2}{*}{ Pressure } & Female & 31 & 4.54 & .74 & & \multirow{2}{*}{-1.62} & \multirow{2}{*}{.106} \\
\hline & Male & 247 & 4.73 & .58 & & & \\
\hline \multirow{2}{*}{ Communication } & Female & 31 & 4.71 & .54 & & \multirow{2}{*}{-.289} & \multirow{2}{*}{.772} \\
\hline & Male & 247 & 4.74 & .40 & & & \\
\hline
\end{tabular}

The independent t-test analysis revealed no statistically significant educational difference in football referees' mean scores on the physical competency ( $t=-1.2 ; \mathrm{p}>0.05)$, game knowledge $(\mathrm{t}=-.684 ; \mathrm{p}>0.05)$, decision-making $(\mathrm{t}=-.1 .07 ; \mathrm{p}>0.05)$, pressure $(\mathrm{t}=$ -1.83; $\mathrm{p}>0.05)$, and communication ( $\mathrm{t}=-.787 ; \mathrm{p}>0.05)$ dimensions of the RFES (Table 3 ).

Table 3. Results of the t-test analysis for education

\begin{tabular}{|c|c|c|c|c|c|c|c|}
\hline Dimensions & Gender & $\mathrm{n}$ & $\bar{x}$ & Sd. & Df & $\mathrm{t}$ & $\mathrm{p}^{*}$ \\
\hline \multirow{2}{*}{ Physical competency } & High school & 45 & 4.42 & .51 & \multirow{10}{*}{276} & \multirow{2}{*}{-1.22} & \multirow{2}{*}{.203} \\
\hline & University & 233 & 4.53 & .52 & & & \\
\hline \multirow{2}{*}{ Game knowledge } & High school & 45 & 4.65 & .42 & & \multirow{2}{*}{-.684} & \multirow{2}{*}{.495} \\
\hline & University & 233 & 4.70 & .41 & & & \\
\hline \multirow{2}{*}{ Decision-making } & High school & 45 & 4.61 & .53 & & 107 & 286 \\
\hline & University & 233 & 4.69 & .44 & & -1.01 & .200 \\
\hline \multirow{2}{*}{ Pressure } & High school & 45 & 4.56 & .94 & & \multirow{2}{*}{-1.83} & \multirow{2}{*}{.067} \\
\hline & University & 233 & 4.74 & .51 & & & \\
\hline \multirow{2}{*}{ Communication } & High school & 45 & 4.78 & .38 & & \multirow{2}{*}{.787} & \multirow{2}{*}{.432} \\
\hline & University & 233 & 4.72 & .42 & & & \\
\hline
\end{tabular}

The results of ANOVA for age groups are presented in Table 4. A significant difference was found in the physical competency $[\mathrm{F}(4,273)=4.48, \mathrm{p}<.05]$ and game knowledge $[\mathrm{F}(4$, $273)=4.00, \mathrm{p}<.05]$ dimensions of the RFES. Tukey's honestly significant difference (HSD) multiple comparison test was performed to identify the groups that significantly differed from each other. 
A significant age difference was found in mean scores on physical competency and game knowledge between the 30-35, 18-23, and 24-29 years age groups. The participants in the 30-35 years age group had higher scores than those in the other two age groups. As for the decision-making dimension, there was a significant difference between the 18-23 and 30-35 years age groups. The participants in the 30-35 age group had higher scores than those in the 18-23 years age group.

Table 4. Results of the analysis of variance for age groups

\begin{tabular}{|c|c|c|c|c|c|c|}
\hline Dimensions & Age & $\mathrm{n}$ & $\bar{x}$ & $\mathrm{~F}$ & $p^{*}$ & Sig. Difference \\
\hline \multirow{5}{*}{ Physical competency } & $18-23$ & 105 & 4.43 & & & \multirow{5}{*}{$\begin{array}{l}(18-23)-(30-35) \\
(24-29)-(30-35)\end{array}$} \\
\hline & $24-29$ & 105 & 4.45 & & & \\
\hline & $30-35$ & 53 & 4.76 & 4.48 & .002 & \\
\hline & $36-41$ & 11 & 4.69 & & & \\
\hline & $\geq 42$ & 4 & 4.65 & & & \\
\hline \multirow{5}{*}{ Game knowledge } & $18-23$ & 105 & 4.64 & \multirow{5}{*}{4.00} & \multirow{5}{*}{.004} & \multirow{5}{*}{$\begin{array}{l}(18-23)-(30-35), \\
(24-29)-(30-35)\end{array}$} \\
\hline & $24-29$ & 105 & 4.64 & & & \\
\hline & $30-35$ & 53 & 4.86 & & & \\
\hline & $36-41$ & 11 & 4.90 & & & \\
\hline & $\geq 42$ & 4 & 4.83 & & & \\
\hline \multirow{5}{*}{ Decision-making } & $18-23$ & 105 & 4.58 & \multirow{5}{*}{3.95} & \multirow{5}{*}{.004} & \multirow{5}{*}{$(18-23)-(30-35)$} \\
\hline & $24-29$ & 105 & 4.66 & & & \\
\hline & $30-35$ & 53 & 4.86 & & & \\
\hline & $36-41$ & 11 & 4.84 & & & \\
\hline & $\geq 42$ & 4 & 4.75 & & & \\
\hline \multirow{5}{*}{ Pressure } & $18-23$ & 105 & 4.61 & \multirow{5}{*}{1.43} & \multirow{5}{*}{.223} & \\
\hline & $24-29$ & 105 & 4.73 & & & \\
\hline & $30-35$ & 53 & 4.81 & & & \\
\hline & $36-41$ & 11 & 4.93 & & & \\
\hline & $\geq 42$ & 4 & 4.83 & & & \\
\hline \multirow{5}{*}{ Communication } & $18-23$ & 105 & 4.70 & \multirow{5}{*}{1.64} & \multirow{5}{*}{.162} & \\
\hline & $24-29$ & 105 & 4.70 & & & \\
\hline & $30-35$ & 53 & 4.84 & & & \\
\hline & $36-41$ & 11 & 4.72 & & & \\
\hline & $\geq 42$ & 4 & 5.00 & & & \\
\hline
\end{tabular}

The ANOVA results for income groups are presented in Table 5. A significant difference was found in the game knowledge $[F(4,273)=2.68, p<.05]$ and decision-making $[F(4,273)$ $=8.23, \mathrm{p}<.05$ ] dimensions of the RFES. A Tukey's HSD multiple comparison test was conducted to identify groups that significantly differed from each other.

Table 5. Results of the analysis of variance for income

\begin{tabular}{ccccccc} 
Dimensions & Income & $\mathrm{n}$ & $\overline{\mathrm{X}}$ & $\mathrm{F}$ & $\mathrm{p} *$ & Sig. Difference \\
\hline & $\leq 407 \$$ & 112 & 4.46 & & & \\
Physical competency & $408 \$-432 \$$ & 30 & 4.44 & & & \\
& $433 \$-576 \$$ & 35 & 4.44 & 1.83 & .123 & \\
& $577 \$-721 \$$ & 21 & 4.62 & & & \\
& $\geq 722 \$$ & 80 & 4.63 & & \\
\hline
\end{tabular}




\begin{tabular}{|c|c|c|c|c|c|c|}
\hline Dimensions & Income & $\mathrm{n}$ & $\bar{x}$ & $\mathrm{~F}$ & $\mathrm{p}^{*}$ & Sig. Difference \\
\hline & $\leq 407 \$$ & 112 & 4.60 & & & \\
\hline & $408 \$-432 \$$ & 30 & 4.81 & & & \\
\hline \multirow[t]{5}{*}{ Game knowledge } & $433 \$-576 \$$ & 35 & 4.70 & 2.68 & .032 & $(\leq 407 \$-\geq 722 \$)$ \\
\hline & $577 \$-721 \$$ & 21 & 4.71 & & & \\
\hline & $\geq 722 \$$ & 80 & 4.77 & & & \\
\hline & $\leq 407 \$$ & 112 & 4.50 & & & \\
\hline & $408 \$-432 \$$ & 30 & 4.86 & & & \\
\hline \multirow[t]{5}{*}{ Decision-making } & $433 \$-576 \$$ & 35 & 4.74 & 8.23 & .000 & $\begin{array}{l}(\leq 407 \$-408 \$-432 \$, \\
433 \$-576 \$, \geq 722 \$)\end{array}$ \\
\hline & $577 \$-721 \$$ & 21 & 4.74 & & & \\
\hline & $\geq 722 \$$ & 80 & 4.82 & & & \\
\hline & $\leq 407 \$$ & 112 & 4.64 & & & \\
\hline & $408 \$-432 \$$ & 30 & 4.58 & & & \\
\hline \multirow[t]{5}{*}{ Pressure } & $433 \$-576 \$$ & 35 & 4.76 & 1.46 & .212 & - \\
\hline & $577 \$-721 \$$ & 21 & 4.80 & & & \\
\hline & $\geq 722 \$$ & 80 & 4.81 & & & \\
\hline & $\leq 407 \$$ & 112 & 4.65 & & & \\
\hline & $408 \$-432 \$$ & 30 & 4.85 & & & \\
\hline \multirow[t]{3}{*}{ Communication } & $433 \$-576 \$$ & 35 & 4.75 & 2.38 & .054 & - \\
\hline & $577 \$-721 \$$ & 21 & 4.75 & & & \\
\hline & $\geq 722 \$$ & 80 & 4.80 & & & \\
\hline
\end{tabular}

A significant income difference was found in mean scores on game knowledge between the $\geq 407$ and the $\geq 722$ \$groups. Participants with an income level of $\geq 722 \$$ had higher scores than those with an income of $\geq 407 \$$. As for the decision-making dimension, there was a significant income difference in mean scores between the $\geq 407 \$, 408 \$-432 \$, 433 \$-576 \$$, and $\geq 722 \$$ groups. Participants with an income level of 2826-3000 TL had higher scores than those in other income groups.

The results of ANOVA for refereeing levels are presented in Table 6. A significant difference was found in the physical competency $[F(4,273)=12.53, p<.05]$ and decision-making $[F(4,273)=2.79, \mathrm{p}<.05]$ dimensions of the RFES. A Tukey's HSD multiple comparison test was conducted to identify groups that significantly differed from each other.

Table 6. Results of the analysis of variance for refereeing level

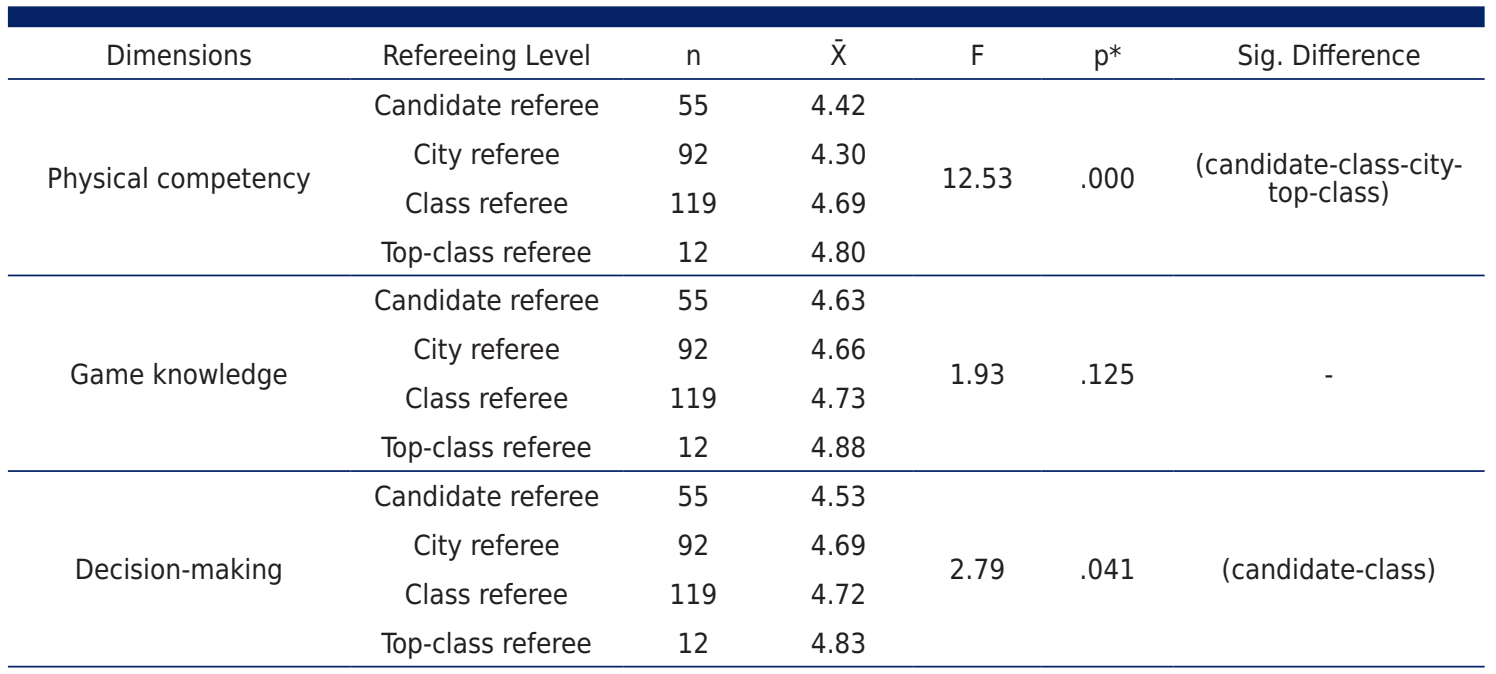




\begin{tabular}{ccccccc} 
Dimensions & Refereeing Level & $\mathrm{n}$ & $\overline{\mathrm{X}}$ & $\mathrm{F}$ & $\mathrm{p} *$ & Sig. Difference \\
\hline \multirow{3}{*}{ Pressure } & Candidate referee & 55 & 4.62 & & & \\
& City referee & 92 & 4.63 & 2.10 & .100 & - \\
& Class referee & 119 & 4.80 & & & \\
& Top-class referee & 12 & 4.88 & & & \\
\hline \multirow{3}{*}{ Communication } & Candidate referee & 55 & 4.80 & & \\
& City referee & 92 & 4.69 & \multirow{2}{*}{297} & \\
& Class referee & 119 & 4.73 & & & \\
& Top-class referee & 12 & 4.87 & & & \\
\hline
\end{tabular}

A significant difference was found in mean scores on physical competency between the candidate and class referee groups according to the refereeing level. Participants in the class referee group had higher scores than those in the candidate referee group. Additionally, the mean scores significantly differed according to the refereeing level between the city, class, and top-class referee groups. Participants in the top-class referee group had higher scores than those in other groups. As for the decision-making dimension, the mean scores significantly differed according to the refereeing level between the candidate and class referee groups. Participants in the class referee group had higher scores than candidate referees.

\section{DISCUSSION AND CONCLUSION}

This study examined the self-efficacy of football referees in relation to multiple variables. The results obtained from the study data indicate no significant difference in gender and education; this can be attributed to similar educational levels among the referees. The lack of gender difference could be related to the lower number of female participants compared to males. With regard to gender, Dereceli et al. [20] found significant differences in male referees' mean scores on the physical competency, communication, and pressure dimensions, but no significant difference was identified in the mean scores on game knowledge and decision-making. In his study on volleyball referees, Sarıdede [21] reported higher levels of self-efficacy in decision-making and game knowledge and overall referee self-efficacy in male referees than in female referees. The study by Adıgüzel [22] on basketball referees established no significant relationship between referees' gender and self-efficacy levels. Adıgüzel's [22] study is similar to this study. Such differences in literature can be attributed to the specific characteristics of study groups [22].

The analysis of self-efficacy levels of football referees according to age revealed a significant difference in physical competency, game knowledge, and decision-making. The results indicate that the referees' levels of physical competency, decision-making, and game knowledge increase with increasing age. The literature review also shows that referee self-efficacy reduces with decreasing age $[17,19,23]$.

The analysis of referees' income levels revealed a significant difference in game knowledge and decision-making. Game knowledge and decision-making levels increased with increasing levels of income. This result may be because of the low refereeing levels of participants with low income.

The analysis of self-efficacy levels of football referees according to refereeing levels revealed a significant difference in physical competency and decision-making. Candidate referee participants had lower scores than class referee participants. In addition, city referee participants had lower scores than class and top-class referee participants. Based on these results, it is possible to suggest that the duration of refereeing has a positive effect on referee self-efficacy [23]. These findings of the present study are supported by the literature [21-24]. 
In conclusion, the present study determined that the increasing age of football referees affected their decisions, and the level of their game knowledge also increased depending on this variable. In this regard, self-efficacy of young referees can be enhanced through training for improving their self-efficacy in the game knowledge, physical competency, and decision-making domains. Furthermore, referees with higher refereeing levels have higher self-efficacy. This study can be replicated with different sample populations. The selfefficacy levels of referees in various sports can be compared with that of football referees.

\section{REFERENCES}

[1] Krustrup P, Dvorak J, Junge A, Bangsbo J. Executive summary: the health and fitness benefits of regular participation in small-sided football games. Scand J Med Sci Sport. 2010;20:132-135. https://doi.org/10.1111/j.1600-0838.2010.01106.x

[2] Čović N, Alić H, Manić G. Effects of recreational soccer on health status improvement. Sport Sci. $2016 ; 18$.

[3] Talović M, Denis Č, Alić H, Jelešković E, Enes D, Ormanović S, Lakota R, Nurković N, Raičković N, Čović N. Strength asymmetry differences between premier league and first league football referees. Acta Kinesiologica, $2018: 1,86-92$.

[4] Brandes L, Franck E, Nüesch S. Local heroes and superstars: an empirical analysis of star attraction in German soccer. J Sports Econ. 2008;9:266-286. https://doi.org/10.1177/1527002507302026

[5] Lindner AM, Hawkins DN. Globalization, culture wars, and attitudes toward soccer in America: an empirical assessment of how soccer explains the world. Sociol Q. 2012;53:68-91. https://doi.org/10.1111/j.1533-8525.2011.01226.x

[6] Mathers JF, Brodie K. Elite refereeing in professional soccer: A case study of mental skills support. J Sport Psychol Action. 2011;2:171-182. https://doi.org/10.1080/21520704.2011.609018

[7] Helsen W, BultynckJB. Physical and perceptual-cognitive demands of top-class refereeing in association football. J Sports Sci. 2004;22:179-189. https://doi.org/10.1080/02640410310001641502

[8] Russell S, Renshaw I, Davids K. How interacting constraints shape emergent decision-making of national-level football referees. Qual Res Sport Exer Health. 2019;11:573-588. https://doi.org/10.1080/2159676X.2018.1493525

[9] Samuel RD, Tenenbaum G, Galily Y. An integrated conceptual framework of decision-making in soccer refereeing. Int J Sport Exer Psychol. 2020:1-23. https://doi.org/10.1080/1612197X.2020.1766539

[10] Guillén F, Feltz DL. A conceptual model of referee efficacy. Front Psychol. 2011;2:25. https://doi.org/10.3389/ fpsyg.2011.00025

[11] Tuero C, Tabernero B, Marquez S, Guillen F. Análisis de los factores que influyen en la práctica del arbitraje [Analysis of the factors affecting the practice of refereeing]. Sociedade Capixaba de Psicologia do Esporte. 2002;1:7-16.

[12] Anderson KJ, Pierce DA. Officiating bias: the effect of foul differential on foul calls in NCAA basketball. J Sports Sci. $\square$ 2009;27:687-694. https://doi.org/10.1080/02640410902729733

[13] Anshel MH, Weinberg RS. Sources of acute stress in American and Australian basketball referees. J Appl Sport Psychol. 1995;7:11-22. https://doi.org/10.1080/10413209508406297

[14] Rainey DW. Sources of stress among baseball and softball umpires. J Appl Sport Psychol. 1995;7:1-10. https://doi. org/10.1080/10413209508406296

[15] Rainey DW. Stress, burnout and intention to terminate among umpires. J Sport Behav. 1995;18:312-323.

[16] Bandura A. Self-efficacy: toward a unifying theory of behavioral change. Psychol Rev. 1977;84:191-215. https://doi. org/10.1037//0033-295X.84.2.191

[17] Karaçam A, Pulur A. The study of adaptation of referee self-efficacy scale (REFS) into Turkish. J Phys Educ Sport Sci. 2017;11(1):118-128.

[18] Karasar N 2007. Scientific research method. [Ankara: Nobel yayın dağıtım].

[19] Myers ND, Feltz DL, Guillén F, Dithurbide L. Development of, and initial validity evidence for, the Referee Self-Efficacy Scale: A multistudy report. J Sport Exerc Psychol. 2012;34:737-765. https://doi.org/10.1123/jsep.34.6.737

[20] Dereceli Ç, Ünlü H, Erbaş MK. Examining of football referees' self-efficacy levels. Sakarya Univ J Educ. 2019;9:69-82. https://doi.org/10.19126/suje.455536

[21] Sarıdede Ç. Analysing self-sufficiency level and decision-making ability of volleyball referees [Master's thesis]. İstanbul Gelişim University Institute of Health Sciences; 2018.

[22] Adıgüzel SN. Examining the relationship between basketball referees' physical self-esteem and self-efficacy. National Journal of Sport Sciences. 2018;2:129-137.

[23] Koçak ÇV. Investigation of the referee self-efficacy levels of the volleyball referees. SPORMETRE Journal of Physical Education and Sport Sciences. 2019;17:33-40.

[24] Karaçam A, Pulur A. Examining the relationship between referee self-efficacy and general self-efficacy levels of football, basketball and handball referees. Univers J Educ Res. 2017;5:1571-1579. https://doi.org/10.13189/ujer.2017.050914 
Baltic Journal of Health and Physical Activity 2021; Supplement (2): 123-130

Journal of Gdansk University of Physical Education and Sport

e-ISSN 2080-9999 